\title{
In vitro digestibilities, predicted glycemic index and sensory evaluation of biscuits produced from composite flours of wheat and processed tiger nut.
}

\author{
Ogunka-Nnoka Charity Uchechi ${ }^{1,}{ }^{*}$, Ben-piakor Torka Esther ${ }^{1}$ and Mepba Horsfall Doobue 2 \\ ${ }^{1}$ Department of Biochemistry, University of Port Harcourt, Choba, Rivers State, Nigeria. \\ 2 Department of Food Science and Technology, Rivers State University, Nkpolu-Oroworukwo, Port Harcourt, Rivers State, \\ Nigeria.
}

Publication history: Received on 23 March 2020; revised on 27 March 2020; accepted on 29 March 2020

Article DOI: https://doi.org/10.30574/gscbps.2020.10.3.0074

\begin{abstract}
This study aimed to evaluate the In vitro digestibilities, predicted glycemic index and sensory evaluation of biscuits produced from composite flours of wheat and processed tiger nut. The tiger nut was sorted and processed by air-drying, blanching, fermentation and dehydration.The processed samples were oven dried at a temperature of $60^{\circ} \mathrm{C}$ for 17 hours before milling into fine flour to blend with wheat flour (Wf) at the ratio of 20:80. Biscuits were produced from blends of wheat flour and processed tiger nut namely: wheat-tiger nut air dried (W-TNA), wheat- tiger nut blanched (W-TNB), wheat- tiger nut fermented (W-TNF) and wheat- tiger nut dehydrated (W-TND). The results of In-vitro protein digestibility of the composite biscuit showed W-TNF biscuit to have the highest digestibility (52.53\%) and W-TND as the least (39.44\%) when compared to wheat flour (48.18\%). Highest starch digestibilities were recorded for composite

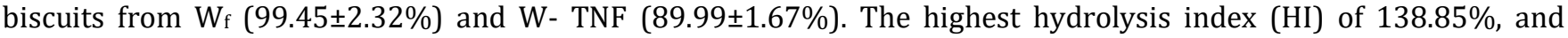
$113.79 \%$ were observed in W-TNF and W-TND respectively; which also resulted in higher predicted glycemic index (PGI) of 115.93\% (W-TNF) and 102.17\% (W-TND).The sensory evaluation revealed that the composite biscuits were generally accepted although there were reductions in aroma, texture and taste of the composite biscuits when compared with the control (Wf)
\end{abstract}

Keywords:In vitro digestibilities; Predicted glycemic index; Sensory evaluation; Biscuit; Wheat; Processed tiger nut.

\section{Introduction}

Wheat flour used for the production of biscuits is insufficient in many regions of the world resulting in importation of the flour by regions with limited supplies [1]. Wheat production in Nigeria is limited due to climatic conditions and wheat is imported to meet local flour needs for baking. As a result of this, huge amount of foreign exchange is spent annually for wheat importation [2]. Efforts have been made to promote the use of composite flour in which locally grown crops with high protein values with the best processing methods replaces a portion of wheat flour thereby decreasing the demand for imported wheat [3]. Soft wheat flour is the suitable flour for biscuit making. This is due to its content of gliadin (a prolamin) and glutamine (glutelin) which undergoes hydration in the presence of water, salt and sugar. This protein forms a visco-elastic matrix known as gluten, which is responsible for the rising nature of dough or permit substantial increase in the volume of baked product of dough and its gas retention capability [4]. There is therefore, a compelling need to develop an adequate substitute for wheat flour. This substitute should be readily available, cheap and capable of replacing wheat in functionality.

Tiger nut (Cyperus esculenta) is of the Cyperacea family and of the same genus as the papyrus plant[5-6].It is an edible perennial grass-likeC4 plant of the sedge family[7]. Common names of the plant are earth almond, yellow nut grass,

\footnotetext{
* Corresponding author: Ogunka-Nnoka Charity Uchechi
} 
ground almond, chufa, bambara groundnut and edible galingale[8-9]. The production and distribution of tiger nut in Nigeria is seasonal; this fluctuates with season of abundance and scarcity which leads to the inability to explore the nutritional content and and its medicinal value[10]. Tiger nut is high in protein that plays important role in human nutrition. A detailed study shows that it makes an excellent source of supplementing proteins in the diet [11]. Tiger nuts have long been recognized to contain almost twice the quantity of starch as potato or sweet potato tubers. Its tuber is a good source of energy [12]. It has high vitamin and mineral contents like iron, phosphorous and calcium. It also has a high content of crude fibre and high level of sulphur containing amino acids which are limited in cereals. These compositions give tiger nut its high nutritive and health value [13]. Its tubers can be eaten raw, roasted with sugar, soaked in water or processed into starch and flour [14]. It can be processed into a milky beverage called "Horchata de Chufa" in Spain or "Atadwe" milk in Ghana [15]. In Nigeria, tiger nut is well grown and available in semi-dried form in Nigerian markets where it is sold locally and consumed uncooked [16]. Tiger nut can be used as composite flour for baking because of its nutritional value. However, processing techniques such as blanching, fermentation and dehydration are means of improving its nutritional value. Composite flour has the added advantage of improving the nutrient value of biscuits and other bakery products especially when cereals are blended with legumes or tubers. Osuntogun [17] suggested the ratio of 50:50 (wheat and non-wheat) flour mixture for biscuit and other bakery products.

Biscuit is an important edible confectionary crisp product of wheat which is deficient in protein and could be enhanced by supplementing the wheat flour with more nutritional pods and other leguminous crops [18]. Biscuit and other baked food products are important items belonging to the class of food that are sold in ready to serve form. All biscuits are expected to be nutritious, contributing valuable quantities of iron, calcium, protein, calorie, fibre and some of the Bvitamins to our diet and daily food requirement. Composite flour has the added advantages of improving the nutrient value of biscuits and other bakery products especially when cereals are blended with legumes.This research however, is aimed at improving the quality of biscuit based products by the addition of processed earth-almond as supplement to wheat flour.

\section{Material and methods}

The wheat, earth-almond (tigernut) and other ingredients used for the production of biscuits were purchased from Bori camp market in Obio/Akpor Local Government Area of Rivers State; Nigeria. All chemical reagents used in this study were of analytical grade.

\subsection{Processing of earth-almond}

Dried tiger nut tubers were carefully selected to remove dust particles and shared into four sets. The first set was further air-dried (TNA) for four days and blended using laboratory miller. The second, third and fourth sets were soaked in water for four days to rehydrate. After which the following processing methods were applied; blanching at $80^{\circ} \mathrm{C}$ for 10 minutes (TNB), soaking in water to ferment for 4 days (TNF) and dehydrated (TND) by oven drying again after rehydration respectively. The $2 \mathrm{nd}-4$ th sets were then oven dried at a temperature of $60^{\circ} \mathrm{C}$ for 17 hours before milling into flour. They were all sieved through 100 mesh size and the flour was stored in a sealed container at $4^{\circ} \mathrm{C}$ until ready for use.

\subsection{Equipment used}

Equipment used include: UV-Visible spectrophotometer, electronic weighing balance, laboratory oven, incubator, centrifuge, electrothermal water bath, heating mantle and kjeldahl apparatus.

\subsection{Chemical / reagents}

Sulphuric acid, hydrochloric acid, distilled water, sodium hydroxide, anthrone reagent, standard glucose and indicator.

\subsection{Preparation of flour blends}

Wheat flour (Wf) and the various processed tigernut samples which included air dried (TNA), blanched (TNB), fermented (TNF) and dehydrated (TND) were used in formulating blends for biscuits making in the proportion of 80:20 respectively. A kenwood mixer was used for mixing samples at speed 6 for 5 minutes to achieve uniform mixing. After which the in-vitro digestibilities, glycemic index and sensory evaluation of the biscuits made from processed wheatearth-almond composite flour were determined. 
Table 1 Composite flour compositions of wheat and procecced earth-almond

\begin{tabular}{ll}
\hline Sample & Blend ratio \\
\cline { 2 - 2 } W-TNA & $80: 20$ \\
W-TNB & $80: 20$ \\
W-TNF & $80: 20$ \\
W-TND & $80: 20$ \\
Wf & 100 \\
\cline { 2 - 2 } W-TNA=Wheat -tiger nut air dried; W-TNB = Wheat- tiger nut blanched; W-T NF = Wheat-tiger nut fermented \\
\end{tabular}

\subsection{Production of wheat-earth-almond biscuits}

The method described by Arisa et al., [19] was used in the production of wheat-earth-almond biscuit. Sugar (75 g) was added to $125 \mathrm{~g}$ of margarine in a Kenwood mixer and mixed at medium speed until fluffy. Whole egg and milk powder were added during mixing and then mixing continued for about $30 \mathrm{~min}$. Composite flour (wheat flour + processed earthalmond), baking powder and flavor were slowly added to the mixture; and kneaded to form dough. It was then rolled on a flat rolling board sprinkled with flour to a uniform thickness of about $0.4 \mathrm{~cm}$, circular cookies of 5.8-6.0 cm were cut, placed in oiled baking trays and baked in the oven at $160^{\circ} \mathrm{C}$ for 15 mins.

\subsection{Determination of In vitro protein digestibility of wheat-earth-almond composite biscuit}

The In-vitro protein digestibility of the composite biscuits and the control (wheat flour) were determined using the method of Saunders et al., [20] and modified by Monsour and Yusuf [21]. A known weight of each sample containing 16 $\mathrm{mg}$ nitrogen was taken and digested with $1 \mathrm{mg}$ of pepsin (Cat. No. P6887, Sigma Chemicals Ltd, USA) in $15 \mathrm{ml}$ of $0.1 \mathrm{MHCl}$ at $37^{\circ} \mathrm{C}$ for $3 \mathrm{~h}$, the pepsin hydrolysed solutions were neutralized with $0.5 \mathrm{M} \mathrm{NaOH}$ and incubated with 6.0 mg of pancreatin (Sigma Chemicals Ltd, Cat. No. P 1750) in $7.5 \mathrm{ml}$ of $0.2 \mathrm{M}$ phosphate buffer at pH 7.6 for $18 \mathrm{~h}$. The reaction was terminated by adding $22.5 \mathrm{ml}$ of $10 \%$ TCA. The TCA soluble fraction was assayed for nitrogen using the micro Kjeldahl method [22]. A blank sample was also determined; protein digestibility was calculated using the formula:

Protein digestibility $\%=$ Nitrogen in supernatant - Nitrogen in blank x 100

\section{Nitrogen in blank}

\subsection{Determination of In vitro starch digestibility of wheat-earth-almond composite biscuits}

The total starch in the control (wheat flour) biscuit and composite (W-TNA, W-TNB, W-TNF, W-TND) flour biscuits developed was determined enzymatically according to the modified method of Goni et al., [23]. The samples were ground to pass through a $0.5 \mathrm{~mm}$ sieve. Subsequently, $25 \mathrm{mg}$ of each sample was dissolved in $6 \mathrm{ml}$ of $2 \mathrm{M} \mathrm{KOH}$ and shaken vigorously for 30 mins at roomtemperature. A stock solution of $\alpha$-amylase was prepared by mixing 20 mg of porcine pancreatic $\alpha$-amylase with $50 \mathrm{ml}$ of $0.2 \mathrm{M}$ phosphate buffer (pH 6.9). One milliliter ( $1 \mathrm{ml}$ ) of the $\alpha$ - amylase solution was added to the sample suspension and incubated at $37^{\circ} \mathrm{C}$ for $45 \mathrm{mins}$ in a shaking water bath. After incubation, $1 \mathrm{ml}$ of $3-$ 5 dinitrosalicyclic acid was immediately added and the mixture was heated for 5 mins to inactivate the enzymes. The solutions after cooling were centrifuged for 10 mins at $3000 x g$, colour absorption of glucose concentration in the supernatant was determined using a spectrophotometer (Cecil 1021, U.K) at a wavelength of 450nm. A standard glucose graph $(\mathrm{Y}=18.719 \mathrm{x}$ and $\mathrm{R} 2=0.9445)$ of $0.02 \mathrm{mg} / \mathrm{l}$ to $0.1 \mathrm{mg} / \mathrm{l}$ was also prepared and the glucose concentrations of each sample obtained. The results were converted to starch by multiplying the percentage glucose concentration by a factor 0.9 .

\subsection{In-vitro starch digestion rate and prediction of glycemic index (PGI)}

The starch digestion rate for the biscuits produced was expressed as the percentage of total starch hydrolysed over time intervals of 30,60, 90 and 120minutes of incubation. The Hydrolysis Index (HI) was derived from the ratio between the areas under the hydrolysis curve of the various products developed and the reference sample (glucose). From the hydrolysis index obtained, the predicted glycemic index (PGI) was calculated using the equation established by Goni et al., [23]. 


$$
\begin{gathered}
P G I=39.7+0.548 \mathrm{HI} \\
H I=\frac{\text { AUC of product }}{\text { AUC of glucose }} \times 100
\end{gathered}
$$

Where, AUC $=$ Area under the curve

\subsection{Sensory evaluation of wheat-earth-almond biscuits}

Sensory evaluation of wheat-earth-almond biscuits were carried out after baking using the method described by Giami and Barber [24]. The sensory attributes included colour, texture, taste and general acceptability were evaluated using a 9 - point hedonic scale with 1 representing the least score (dislike extremely) and 9, the highest score (like extremely) as described by Iwe [25].

\subsection{Statistical analysis}

Results were expressed as mean values and standard deviation of duplicate determinations. The obtained data were analysed using a one way Analysis of Variance (ANOVA) using Statistical Package for Social Science (SPSS) version 20.0 software 2011 (Soft Inc. Tulsa, USA) to test the level of significance $(\mathrm{p}<0.05)$. Duncan New Multiple range Test was used to separate the means where significant differences existed.

\section{Results}

In vitro starch hydrolysis rates of biscuits produced from wheat flour and processed tiger nut are shown in Table 2 . The hydrolysis of biscuits produced from blends of Wheat flour and processed tiger nut varied with digestion time. Starch digestibility at various time (0-180 minutes) for composite biscuits produced from W-TNA, W-TNB, W-TNF, W-TND and $\mathrm{W}_{\mathrm{f}}$ are within the ranges of; $18.68-59.61 \%, 15.48-77.72 \%, 22.14-89.99 \%, 52.11-74.12 \%$ and $63.72-99.45 \%$ respectively. Highest starch digestibilities were recorded for biscuits from $\mathrm{W}_{\mathrm{f}}(99.45 \%)$ and $\mathrm{W}$-TNF (89.99\%).

Table 2Percentage (\%) starch hydrolysis of biscuits produced from wheat flour and processed earth-almond.

\begin{tabular}{llllll}
\hline Time(min) & W-TNA & W-TNB & W-TNF & W-TND & W $_{\mathbf{f}}$ \\
\hline 0 & $34.47 \pm 0.04^{\mathrm{a}}$ & $31.73 \pm 0.00^{\mathrm{a}}$ & $89.99 \pm 0.12^{\mathrm{c}}$ & $52.11 \pm 0.04^{\mathrm{b}}$ & $63.72 \pm 0.33^{\mathrm{b}}$ \\
30 & $51.57 \pm 0.00^{\mathrm{b}}$ & $33.57 \pm 0.02^{\mathrm{a}}$ & $66.51 \pm 0.02^{\mathrm{bc}}$ & $74.12 \pm 0.06^{\mathrm{c}}$ & $99.45 \pm 0.24^{\mathrm{d}}$ \\
60 & $59.61 \pm 0.14^{\mathrm{b}}$ & $77.72 \pm 0.08^{\mathrm{b}}$ & $48.38 \pm 0.23^{\mathrm{a}}$ & $62.60 \pm 0.34^{\mathrm{b}}$ & $70.11 \pm 0.23^{\mathrm{b}}$ \\
90 & $18.68 \pm 0.12^{\mathrm{a}}$ & $15.48 \pm 0.04^{\mathrm{a}}$ & $39.92 \pm 0.19^{\mathrm{b}}$ & $70.92 \pm 0.87^{\mathrm{c}}$ & $77.67 \pm 0.29^{\mathrm{c}}$ \\
120 & $28.89 \pm 0.04^{\mathrm{a}}$ & $40.55 \pm 0.07^{\mathrm{b}}$ & $60.21 \pm 0.31^{\mathrm{c}}$ & $64.94 \pm 0.91^{\mathrm{c}}$ & $81.90 \pm 0.34^{\mathrm{d}}$ \\
150 & $45.86 \pm 0.56^{\mathrm{b}}$ & $24.89 \pm 0.84^{\mathrm{a}}$ & $22.14 \pm 0.15^{\mathrm{a}}$ & $71.42 \pm 0.75^{\mathrm{c}}$ & $83.34 \pm 0.97^{\mathrm{c}}$ \\
180 & $40.10 \pm 0.87^{\mathrm{b}}$ & $20.48 \pm 0.00^{\mathrm{a}}$ & $38.93 \pm 0.05^{\mathrm{b}}$ & $53.28 \pm 0.94^{\mathrm{c}}$ & $79.43 \pm 0.33^{\mathrm{d}}$
\end{tabular}

Values are means \pm standard deviation of duplicate samples. Mean values bearing different superscript in the same row differ significantly ( $\mathrm{p}<0.05$ ). *W-TNA=Wheat -tiger nut air dried,W-TNB = Wheat- tiger nut blanched, W-TNF =Wheat-tiger nut fermented, W-TND =Wheat-tiger nut dehydrated, $\mathrm{W}_{\mathrm{f}}=$ Wheat flour

The Area Under Curve (AUC), Hydrolysis Index (HI) and Predicted Glycemic Index (PGI) are shown in Table 3. The highest hydrolysis index (HI) of $138.85 \%$ was observed in W-TNF and $113.79 \%$ in W-TND which resulted in higher predicted glycemic index (PGI) of $115.93 \%$ for $\mathrm{W}$-TNF and $102.17 \%$ for $\mathrm{W}$-TND. The values were significantly different from that obtained for $\mathrm{W}_{\mathrm{f}}$ with $\mathrm{HI}$ of $44.67 \%$, PGI $64.22 \%$ and $\mathrm{W}$-TNA with $\mathrm{HI}$ value of $48.00 \%$ and PGI of $66.05 \%$.

Table 3 Calculated hydrolysis index and predicted glycemic index

\begin{tabular}{llll}
\hline Samples & AUC & HI & GI \\
\hline
\end{tabular}




\begin{tabular}{llll}
\hline W-TNA & $55.78 \pm 4.25^{\mathrm{d}}$ & $48.00 \pm 3.65^{\mathrm{d}}$ & $66.05 \pm 2.01^{\mathrm{d}}$ \\
W-TNB & $94.63 \pm 2.66^{\mathrm{c}}$ & $81.44 \pm 2.29^{\mathrm{c}}$ & $84.41 \pm 1.26^{\mathrm{c}}$ \\
W-TNF & $161.35 \pm 4.38^{\mathrm{a}}$ & $138.85 \pm 3.77^{\mathrm{a}}$ & $115.93 \pm 2.07^{\mathrm{a}}$ \\
W-TND & $132.23 \pm 4.35^{\mathrm{b}}$ & $113.79 \pm 3.74^{\mathrm{b}}$ & $102.17 \pm 2.05^{\mathrm{b}}$ \\
W $_{\mathrm{f}}$ & $51.91 \pm 0.68^{\mathrm{d}}$ & $44.67 \pm 0.55^{\mathrm{d}}$ & $64.22 \pm 0.30^{\mathrm{d}}$ \\
\hline
\end{tabular}
Values are means \pm standard deviation of duplicate samples.Mean values bearing different superscript in the same column differ significantly
$(\mathrm{p}<0.05)$.

$\mathrm{AUC}=$ area under the curve; $\mathrm{HI}=$ hydrolysis index; $\mathrm{GI}=$ glycaemic index

In vitro protein digestibilities are presented in Figure 1.The protein digestibilities for biscuits from $\mathrm{W}$-TNF (52.53\%) and Wf $(48.18 \%)$ were significantly $(\mathrm{p}<0.05)$ higher than the biscuits from W-TND (39.44 \%); but not significantly higher than biscuits from W-TNB (48.16\%) and W-TNA (43.77 \%).
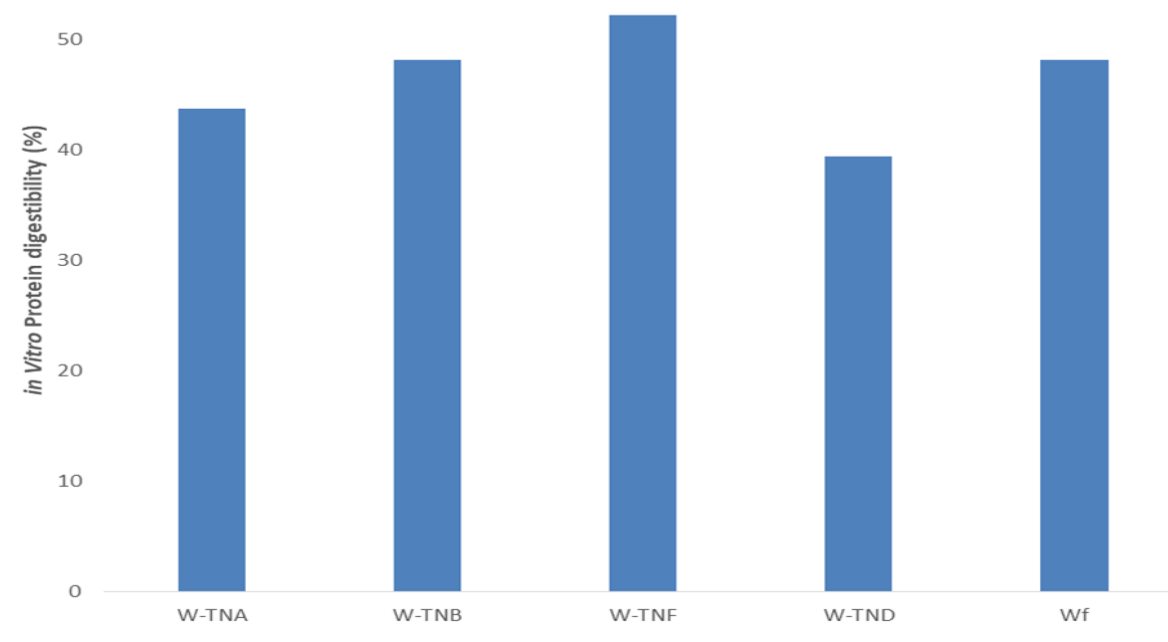

Figure 1 In vitro protein digestibility of composite biscuits from wheat flour and processed tiger nut flours

Mean score for sensory evaluation of biscuit given in Table 4 revealed significant differences $(p \leq 0.05)$ between treatments for sensory attributes like taste, colour and texture. Sensory rating of biscuit for colour shows that sample W-TND was rated highest (7.90), followed by sample Wf (7.85) and sample W-TNB (7.70) while sample W-TNA was rated lowest (6.12).

Table 4 Sensory evaluation of biscuit produced form wheat and processed tiger nut

\begin{tabular}{clllll}
\hline Sample & Colour & Taste & Texture & Aroma & Acceptability \\
\hline W-TNA & $6.12 \pm 0.22 \mathrm{a}$ & $4.82 \pm 0.18 \mathrm{a}$ & $4.61 \pm 0.22 \mathrm{a}$ & $5.33 \pm 0.23 \mathrm{a}$ & $4.45 \pm 0.01 \mathrm{a}$ \\
$\mathrm{W}$-TNB & $7.70 \pm 0.09 \mathrm{~b}$ & $7.34 \pm 0.19 \mathrm{c}$ & $6.48 \pm 0.18 \mathrm{c}$ & $6.84 \pm 0.18 \mathrm{~b}$ & $4.86 \pm 0.00 \mathrm{a}$ \\
$\mathrm{W}-\mathrm{TNF}$ & $6.62 \pm 0.13 \mathrm{a}$ & $5.83 \pm 0.23 \mathrm{~b}$ & $5.62 \pm 0.18 \mathrm{~b}$ & $6.49 \pm 0.22 \mathrm{~b}$ & $4.34 \pm 0.04 \mathrm{a}$ \\
W-TND & $7.90 \pm 0.10 \mathrm{~b}$ & $5.76 \pm 0.24 \mathrm{~b}$ & $6.07 \pm 0.20 \mathrm{c}$ & $6.84 \pm 0.17 \mathrm{~b}$ & $4.21 \pm 0.03 \mathrm{a}$ \\
Wf & $7.85 \pm 0.13 \mathrm{~b}$ & $7.42 \pm 0.17 \mathrm{c}$ & $6.91 \pm 0.22 \mathrm{c}$ & $7.06 \pm 0.22 \mathrm{~b}$ & $4.89 \pm 0.03 \mathrm{a}$ \\
\hline Values are means \pm standard deviation of duplicate samples.Mean values bearing different superscript in the same column differ significantly \\
$(\mathrm{p}<0.05)$.
\end{tabular}

\section{Discussion}

Starch digestibility involves the disruption of their complex cellular structure. The variation in digestion time may be attributed to the fact that the heat treatment applied in some cases may not be sufficient to fully gelatinize starch granules thus making it resistant for $\alpha$-amylase digestion.The digestibilities observed with the composite biscuits agree 
with the report of Kiin-Kabari and Giami, [26]. Starch digestibility for wheat flour biscuit was higher than the composite biscuits. Increase in total starch hydrolysed inbiscuit from frementation blend (W-TNF) could be attributed to the fact that fermentation activates starch hydrolyzing enzymes such as alpha-amylase and maltase which degrade starch into maltodextrins and simple sugars respectively $[10,13]$.

Glycemic index gives an idea about how fast the body converts carbohydrate in a food into glucose. High glycemic index reported in this study agrees with the report of Kiin-Kabari and Giami, [26]. The lowest HI and PGI were recorded for wheat flour. The result showed that the lower HI subsequently led to the reduced predicted glycemic index (PGI). Wheat flour has been reported to have glycemic index of 54 [26]. This value differs slightly from what the present study reported. This difference may be attributed to factors such as processing methods, product compositions such as proteins [27] and fat [28]. According to Foster-Powell et al., [29] glycemic index of foods are classified as follows: low $(\mathrm{GI}<55)$, medium (GI 56-69) and high (GI> 70). This may be that wheat contains carbohydrates whose bulk may consist of non-starch polysaccharides with a low GI. Studies have shown that a low GI diet not only improves certain metabolic consequence of insulin resistance but also reduces insulin resistances [30]. In addition to improvement in glucose and lipid metabolism, there are indications of improvements in fibrinolytic activity suggesting beneficial roles in the management of diabetes and cardiovascular diseases [31]. Although, predicted glycemic index for white bread had been reported to be $94.61 \%$ [32] which compares with the present study. The highest HI with a corresponding GI was observed in the fermented composite biscuit. Fermentation has dual effect on glycemic index (GI). Some studies have reported increased [33] while others have reported decreased [34] GI after consumption of fermented foods. The low GI of fermented food has been attributed to the short-chain organic acids produced during fermentation such as lactic acid, acetic acid, and propionic acid [35]. While the increase was likely due to ease of digestion and absorption of glucose; which is as a result of degradation of fiber by microorganisms during fermentation. However, there is still gap on scientific knowledge on the increase in GI due to fermented cereal and legumes products.

In vitro protein digestibility has the potential to give useful measures of in vivo protein and amino acid digestibility for humans.In this study, In vitro protein digestibility is high with fermented product because during fermentation there is an increase in the release of proteolytic enzymes that can not only degrade the antinutrient which complex with proteins but also brake down complex proteins thereby liberating more peptides and amino acids [36]. The protein digestibility level recorded in this study was lower to the digestibility reported by Kiin-Kabari and Giami [26]. Possible reason for the low digestibility recorded for wheat flour biscuit may be due to the interraction of various components during formulation.

The result for sensory evaluation shows that wheat flour sample was most preferred by the panelist in terms of taste, aroma, acceptability and texture; while W-TND was preferred in terms of colour. Processing of tiger nut did not affect the sensory evaluation of the composite biscuits. This may be attributed to the ratio of the wheat $(80 \%)$ and the various processed earth-almond (20\%) flours. Colour is a very important parameter in judging properly baked biscuits that not only reflect the suitable raw material used for the preparation but also provides information about the formation and quality of the product [37]. Darker colour was observed with composite flour biscuits compared to the control. The change in colour may be due to the non-enzymatic reaction between reducing sugar molecules and additional protein in wheat flour and earth-almond flour respectively. The observed darker colour of biscuits produced from composite flours has been earlier reported by Neha and Ramesh [38]. Evaluation of taste showed that W-TNA had the least value (4.82). The decline in taste could be ascribed to the effect of non-enzymatic browning reactions resulting from the reaction between amino acids and free sugars causing slight bitterness during baking [39].

In terms of aroma, composite flour biscuits were rated lower compared to the control. A different observation was noted by supplementing wheat flour with mustard protein concentrate and cotton seed flour in the production of cookies [40]. It is important to note that modification in production process and slight change in the physical, chemical properties of ingredients in blended foods may also affect the sensorial quality.

\section{Conclusion}

Results from this research have shown that when processed tiger nut was used to substitute with wheat flour in the production of biscuits, digestibilities improved although improvement was dependent on processing. HI and PGI of WTNA were low and alike to Wf values; this is an indication that W-TNA can serve as food source for obesity and diabetic patients. Biscuit prepared fom W-TNB, compared favourably in physical characteristics with the control (Wf). Sensory attributes of the biscuits were not adversely affected since there was general acceptability of all the biscuits. 


\section{Compliance with ethical standards}

\section{Acknowledgments}

The authors would like to thank the Department of Biochemistry, University of Port Harcourt and Department of Food Science and Technology, Rivers State University, Nkpolu-Oroworukwo, Port Harcourt, Rivers State, Nigeria for providing the facilities for this study.

\section{Disclosure of conflict of interest}

All authors declare that they have no conflict of interest.

\section{References}

[1] Zouari R, Besbes S and Ellouze S. (2016). Cookies from Composite Wheat-Sesame Peels Flours; Dough Quality and Effect of Bacillus Subtilis SPB1247 Biosurfactant Addition. Food Chemistry,194, 758-769.

[2] Wilson GF. (1987). Status of banana and plantain in West Africa: In Bananas and Plantain Breeding strategies. Procedure of International workshop on plantain and Bananas.

[3] Giami SY, Amasisi T and Ekiyor G. (2004). Comparison of bread making properties of composite flour from kernels of roasted and boiled African breadfruit (Treculia Africana decne) seeds. Journal of Material Research, $1(1), 16025$.

[4] Okaka JC. (1997). Cereals and legumes: Storage and Processing Technology. Data and microsystem publishers, Enugu, Nigeria, 11-12.

[5] Odoemelan SA. (2003). Chemical composition and functional properties of conophor nut (Tetracarpidium conophorum) flour. International Journal of Food Science and Technology, 38, 729-734.

[6] Belewu MA and Belewu KY. (2007). Comparative physico-chemical evaluation of tigernut, soybean and coconut milk sources. International Journal of Agriculture and Biology, 9, 785-787.

[7] Turesson H, Marttila S, Gustavsson KE, Hofvander P, Olsson ME, Bülow L, Stymne S and Carlsson AS. (2010). Characterization of oil and starch accumulation in tubers of Cyperus esculentus var. sativus (Cyperaceae): A novel model system to study oil reserves in nonseed tissues. American Journal of Botany, 97(11), 1884-1893.

[8] Defelice MS. (2002). Yellow nuts edge Cyperus esculentus L.-Snack food of the gods. Weed Technology, 16(4), 901-907.

[9] Sánchez-Zapata E, Fernández-López J and Angel Pérez-Alvarez J. (2012). Tiger nut (Cyperus esculentus) commercialization: health aspects, composition, properties, and food applications. Comprehensive Reviews in Food Science and Food Safety, 11(4), 366-377.

[10] Umaru HA, Umaru IJ, Aminu A and Kerenhappuch IU. (2018). Influence of different processing methods on proximate and anti- nutritional value of tigernuts (Cyperus esculentus L.). GSC Biological and Pharmaceutical Sciences, 3(3), 29-34.

[11] Nwosu JN. (2013). Production and Evaluation of Biscuits from Blends of Bambara Groundnut and Wheat Flours. International Journal of Food Nutritional Science, 2(1), 4-9.

[12] Arafat S, Gaafar A, Basuny A and Nassef L. (2009). Chufa tubers (Cyperus esculentus L.): As a new source of food. World Applied Journal of Science, 7, 151-156.

[13] Agbaje RB, Oyetayo VO and Ojokoh AO. (2015). Effect of fermentation methods on the mineral, amino and fatty acids composition of Cyperus esculentus. African Journal of Biochemistry Research, 9(7), 89-94.

[14] Oladele AK and Aina J0. (2007). Chemical Composition and Functional Properties of Flour produced from two varieties of Tiger nut (Cyperus esculentus). African Journal of Biotechnology, 6(21), 2473-2476.

[15] Rita ES. (2009). The use of tiger nut (Cyperus esculentus), cow milk and their composite as substrates for yoghurt production. Pakistan Journal of Nutrition, 6, 755-758.

[16] Omode AA, Fatoki OS and Olaogun KA. (1995). Physicochemical properties of some underexploited and nonconventional oil seeds. Journal of Agriculture and Food Chemistry, 43, 2850-2853. 
[17] Osuntogun, A (1987). Keynote Address Policies for self-reliance in the supply of raw materials for Nigeria Baking Industry. Procedure of NIFST Workshop held at Ile-Ife on 18th - 21st, $11-20$.

[18] Meyer LH. (1987). Cereals and their uses. In: Food Chemistry. Luton Publishers, London, 317 - 327.

[19] Arisa NN, Adelakan AO, Alamu AE and Ogunfowora EJ. (2013). The effect of pretreatment of plantain (Musa paradisiaca) flour on the pasting and sensory characteristics of biscuit. International Journal of Food and Nutrition Science, 2(1), 10-23.

[20] Saunders RM, Connor MA, Booth AN, Bickhoff EM and Kohler GO. (1973). Measurement of digestibility of alfalfa protein concentrates by in-vivo and in-vitro methods. Journal of Nutrition, 103, 530-535.

[21] Monsour MA and Yusuf HKM. (2002). In-vitro protein digestibility of lathyrus pea (Lathyrus sativus), lentil (Lens alimaris) and chickpea (Cier arietinum). International Journal of Food Science and Technology, 37(1), 97-99.

[22] AOAC. (1990). Official Methods of Analysis. 15th Edition. Association of Official Analytical Chemists, Washington, D.C. U.S.A. 22.

[23] Goni I, Garci-Alonso A and Suara-Calirto B. (1997). Starch hydrolysis procedure to estimate glycemic index. Nutrition Research, 17, 427-437.

[24] Giami SY and Barber LI. (2004). Utilization of protein concentrates from ungeminated, and germinated fluted pumpkin (Telfairia occidentalis Hook) seeds in cookies formulations. Journal of the Science of Food and Agriculture, 84, 1901-1907.

[25] Iwe MO. (2010). Handbook of Sensory methods and analysis. Enugu, Nigeria: Rejoint Communication Science Ltd. 75-78.

[26] Kiin-Kabari DB and Giami SY (2015). Physico chemical properties and in-vitro protein digestibility of non-wheat cookies prepared from plantain flour and bambara groundnut protein concentrate. Journal of Food Research, 4 , (2), 78-86

[27] Manders RT, Wagenmakers AJ, Koopman R, Rorenc AH, Menheere PP, Schaper NC and Van-Loon LJ. (2005). Coingestion of a protein hydrolysate and amino acid mixture with carbohydrate improves plasma glucose disposal in patients with type 2 diabetes. American Journal of Clinical Nutrition, 82(1), 76-83.

[28] Collier G, McLean A and O'Dea K. (1984). Effect of co-ingestion of fat on the metabolic responses to slowly and rapidly absorbed carbohydrate. Diabetologia Croatiea, 26, 50-54.

[29] Foster-Powell K, Holt SH and Brand-Miller JC. (2002). International table of glycemic index and glycemic load values. The American Journal of Clinical Nutrition, 76(1), 5-56.

[30] Del-Prato S, Leonctti F, Simonson DC, Sheehan P, Matsuda M and Defronzo RA. (1994). Effect of sustained physiologic hyperinsulinemia and hypergly caemia on insulin secretion and insulin sensitivity in man. Diabetologia, 37, 1025-1035.

[31] Jarvi AE, Karistrom BE, Granfeldt YE, Bjorckl KE, Asp NG and Vessby BH. (1999). Improved glycemic control and lipid profile and normalized fibrinolytic activity on a low-glycemic index diet in type 2 diabetic patients. Diabetes Case, 22, 10-18.

[32] Capriles VD, Coelho KD, Guerra-Matias AC and Areas JA. (2008). Effect of processing methods on Amaranth starch digestibility and predicted glycemic index. Journal of Food Science, 73(7), H160-H164.

[33] Ihediohanma NC. (2011). Determination of the glycemic indices of three different cassava granules (garri) and the effect of fermentation period on their glycemic responses. Pakistan Journal of Nutrition, 10, 6-9.

[34] Mlotha V, Mwangwela AM, Kasapila W, Siyame EW and Masamba K. (2016). Glycemic responses to maize flour stiff porridges prepared using local recipes in Malawi. Journal of Food Sciences and Nutrition, 4, 322-328.

[35] Ostman EM, Granfeldt Y, Persson L and Bjorck IME. (2005). Vinegar supplementation lowers glucose and insulin responses and increases satiety after a bread meal in healthy subjects. European Journal of Clinical Nutrition, 59, 983-988.

[36] Pranoto Y, Anggrahini S and Efendi Z. (2013). Effect of natural and Lactobacillus plantarum fermentation on in vitro protein and starch digestibilities of sorghum flours. Food Bioscience, 2, 46-52.

[37] Abdulwahab ID, Abubakar LG, Nwachukwu NG, Mohammed A and Ibrahim AS. (2018). Production and Quality of Biscuits from Composite Flours. Journal of Food Science and Engineering, 8, 241-247 
[38] Neha M and Ramesh C. (2012). Development of functional biscuit from soy flour and rice bran. International Journal of Agricultural and Food Science, 2(1), 14-20.

[39] Makinde FM and Adeyemi AT. (2018). Quality characteristics of biscuits produced from composite flours of wheat, corn, almondand coconut. Annals of Food Science and Technology, 19(2), 216-225.

[40] Rajput LP, Haridas RP and Shurpalekar SR. (1988).Use of unconventional sources in high protein biscuits. Journal of Food Science and Technology, 25(1), 31-34.

\section{How to cite this article}

Ogunka-Nnoka CU, Ben-piakor TE and Mepba HD. (2020). In vitro digestibilities, predicted glycemic index and sensory evaluation of biscuits produced from composite flours of wheat and processed tiger nut. GSC Biological and Pharmaceutical Sciences, 10(3), 164-172. 